\title{
3. Structural mechanisms affecting policy subsystems activity: beyond individual and group behavioral propensities in policy design and policy change
}

\section{Michael Howlett}

\section{INTRODUCTION: POLICY MECHANISMS AND POLICY CHANGE}

Policy sectors constitute distinct policy regimes consisting of the current collectively accepted definition of an issue, the current relevant policies (laws, regulations, fiscal instruments, government programs and relationships), and the actors and institutions (both inside and outside government) actively engaged in implementing and modifying them (Harris and Milkis, 1989; Eisner, 1994a, 1994b). These regimes are constructed at the "subsystem" level (McCool, 1998), that is, as subsets of political, social and economic systems and the various actors and activities of which those are comprised.

According to Sabatier (1998, p. 99), "[a] subsystem consists of actors from a variety of public and private organizations who are actively concerned with a policy problem or issue, such as agriculture, and who regularly seek to influence public policy in that domain." Such subsystems, he argued, provide "the most useful unit of analysis for understanding the overall policy process," superior to the use of other units such as government organizations or programs.

How these subsystems operate and what impact they have on policies and vice versa is a long-standing question in the policy sciences (Cater, 1964). Often these subsystems are viewed as examples of a general class of stable "homeostatic" systems that are self-adjusting or self-equilibrating in routine circumstances and often thought of as changing only under the pressure of external shocks or "jolts" that introduce new extraneous elements into the system, throwing them out of equilibrium (Sabatier, 1988; Aminzade, 1992). This notion of the exogenous nature of subsystem change focuses analytical attention on the various types of external crises that could provoke changes in 
policy goals and objectives, and instruments or their settings, an approach that is common in comparative policy studies, for example (Wilsford, 1994).

However, the empirical purchase of the metaphor of contemporary policy-making as a homeostatic system has increasingly been challenged in the policy sciences. Contemporary policy thinking now tends to favor more adaptive constructs in which it is assumed that policy actors not only react to external changes but can also affect their own environments and, as a result, can endogenously induce or prevent significant policy change (Buckley, 1968; Daneke, 1992; Smith, 2000).

This reconceptualization has led to greater efforts to measure, chronicle, and account for the precise mechanisms that are activated in policy changes and of the capacities of the instruments that activate them. Many of these mechanisms are operative at the level of individual or group behavior and include mechanisms such as the propensity of individuals to search for advantage or normative harmony, status and prestige discussed in other chapters in this volume, as well as group behavior such as rent- or influence-seeking, which motivate policy-relevant aspects of organizational dynamics and activities.

As shall be discussed below, however, there is a third class of such "first-order" mechanisms, those that directly affect policy actors, one in which policy network relationships alter as new nodes and links are added to subsystems. These structural adaptations can be triggered by government policy interventions that introduce new actors and ideas into policy structures, often through the deployment of "procedural" policy tools specifically intended to trigger this adaptive reflex in policy subsystem structure and activity (Howlett, 2000; Lang, 2016). These activators and structural mechanisms are key ones that can precipitate and reshape specific types of policy behavior on the part of network members. By affecting the number and type of anodes and links of a policy subsystem, these changes in turn can affect the nature of policy deliberations and discourses, and ultimately policy outputs (Lang, 2016).

\section{POLICY CHANGE: THE DESIGN-MECHANISM PROBLEMATIC}

In a widely cited study, Peter Hall identified three different levels or "orders" of policy outputs associated with alterations in policy means or goals: the settings of policy instruments; the types of instruments; and the goals of policy (Hall, 1993). ${ }^{1}$ However, as Daugbjerg correctly pointed out, the logic behind Hall's insight in analytically distinguishing between instruments and settings is that policy outputs differ not only according to whether the goals or means of policy are affected, but also according to differences in their conceptual or practical aspects (Daugbjerg, 1997). 
Taking these two dimensions (conceptual and practical) into account yields a four-fold taxonomy of policy outputs: goals, objectives, instruments, and settings or calibrations. Any or all four of these four basic policy outputs can be affected by change processes. At the level of ideas and concepts, for example, policy change can involve alteration or reformulation of abstract policy goals or ends, or of the general nature of types of policy instruments used as the means to implement those goals. At a more practical or programmatic level, change can involve shifts in program objectives or the calibration of specific policy instruments in use.

How exactly such changes occur and why remains an outstanding question in the policy sciences (Capano, 2012). Adopting a mechanistic perspective on this issue, however, is very helpful and quite revealing of the actual processes through which change takes place (Bunge, 1997, 2004; Glennan, 2002; Kay and Baker, 2015). Although most explanations of policy activity based on mechanistic logics to date have been firmly situated at the level of individual behavior and have followed the precepts of methodological individualism (Miller, 1978; Hedström and Ylikoski, 2010), there is also a set of studies that have emphasized the significance of institutional and other structural elements of public policy (Peters, 1992; Schmidt, 2008) with which mechanistic studies have not yet grappled. The logic of this third level of policy mechanisms and how it is related to the individual and group levels is set out below.

\section{The Logic of Mechanisms: Policy Change as Behavioral Change}

Policy changes come about as governments and social actors wrestle with the basic problematic and expectations of policy interventions. As set out in Figure 3.1 , the mechanisms approach to policy-making and policy dynamics centers around the idea that the use of policy tools activates certain propensities on the part of policy actors, leading to changes in their behavior and policy outputs.

This is a process that is seen as involving a complex causal chain centered around existing policy behaviors and policy-making contexts, policy interventions that trigger - intentionally, consciously or not - policy mechanisms, and changing or affecting "target" behavior in some new direction (Hedström and Swedberg, 1996, 1998; Falleti and Lynch, 2009; Hedström and Ylikoski, 2010).

This approach thus views policy-making as largely about affecting behavioral changes in target populations, with policy instruments used as a means to influence a shift from behavior (1) to a reformed or now behavior (1A or 2) (Balch, 1980).

Exactly how policy instruments activate mechanisms, and which mechanisms are involved in these processes, however, is not well known. That is, the behavioral consequences and mechanisms activated by policy tools and how "tools match targets" (Howlett, 2018) remains an outstanding research question and agenda that the chapters in this book address. 


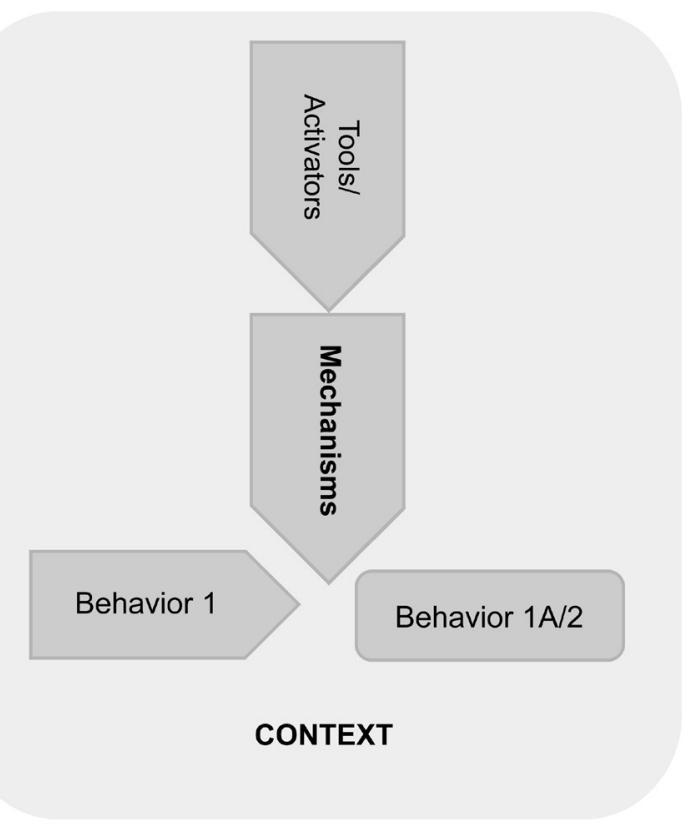

Figure 3.1 The behavioral expectations of policy design

The linkages between policy instrument invocation and behavioral or policy change are very rich. As Figure 3.2 shows, a mechanistic process of behavioral change involves at least four linkages, all of which are affected by contextual aspects present at the exact moment at which instruments are invoked and mechanisms triggered. These are:

1. The link between tools and the governing resources present at any moment in time.

2. The link between resources and the mechanisms that tools activate.

3. The links between the mechanisms and the actual behavioral changes that occur post-activation.

4. The link between changes in behavior and changes in policy outputs.

All four of these linkages are susceptible to various barriers and impediments to instrument choices, mechanism activation, reception and impact. That is, each link in this chain is affected by contextual factors that can serve to block or make the linkages across the tools-output chain problematic, that is, difficult to predict and control (Falleti and Lynch, 2009). There are many such barriers and factors, which include the preferred policy style and governance 


\section{Design-Output Linkages and Contextual Factors}

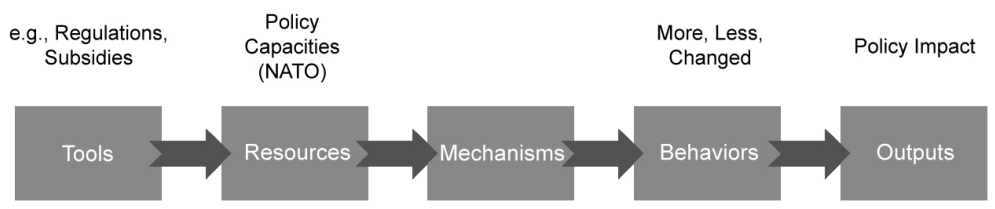

Figure 3.2 Links in the policy instrument-mechanism-output chain

mode, which can affect preferences for certain tools over others (Howlett and Rayner, 2013; Howlett, 2017); the various capacity strengths and weaknesses that can limit the capability of governments to use particular tools or eliminate them altogether (Wu, Ramesh and Howlett, 2015; Howlett and Ramesh, 2016); possible countervailing demands and constraints on behavioral change that can undermine the effect and impact of a mechanism on subsequent behavioral change (Weaver, 2014, 2015; Howlett, 2018); as well as various kinds of implementation and other issues that can lessen, or enhance, policy outputs (Hupe and Hill, 2016; Lindqvist, 2016). These potential contextual factors are set out in Figure 3.3.

\section{OPENING UP THE BLACK BOX OF POLICY MECHANISMS: INDIVIDUAL-, GROUP- AND SUBSYSTEM-LEVEL MECHANISMS}

This discussion of the general logic of a mechanistic approach to policy-making, of course, begs the question of what is in the "black box" at the center of the analysis. That is, what mechanisms drive these processes of policy change? What are the mechanisms that lead more or less regularly to one type of output even if this regularity is limited to some circumstances and not others? Who do they affect, and how?

In general, two kinds of mechanisms can be identified: those that more or less directly affect actor behavior and those that involve learning and more reflective activities. The latter second-order mechanisms are important, but are covered elsewhere (Levitt and March, 1988). The discussion below centers in the first instance on those mechanisms that more directly affect actor behavior. 


\section{Design-Output Linkages and Contextual Factors}

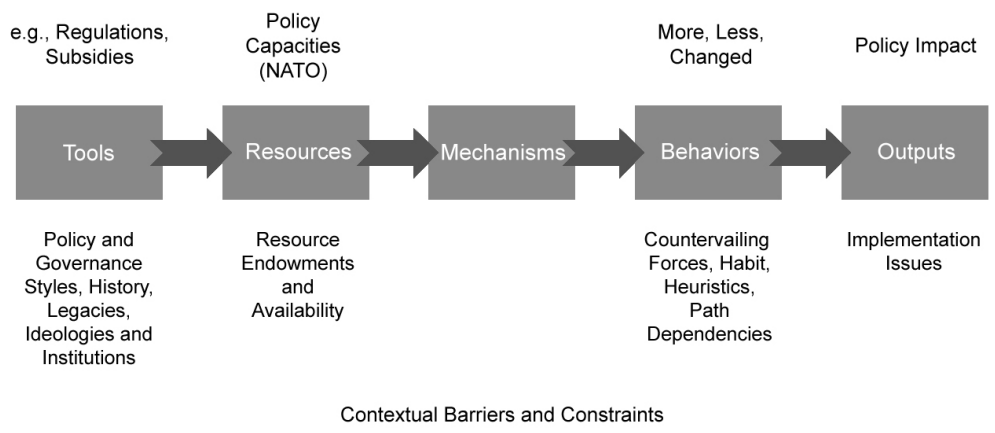

\section{Figure 3.3 Context-related mechanism constraints}

These kinds of "first-order" mechanisms have received treatment in the literature before, which has variously termed them "micro-meso-macro" or "transformational," "action-forcing" or "situational" (Hedström and Swedberg, 1998; Hedström and Ylikoski, 2010). However, these definitions are quite vague as to what exactly is micro and what macro, for example, in the case of the former, and why only three types exist in the latter case. A more robust and clear way to distinguish between such mechanisms is to look at what or whose behavior is being affected. Here a central distinction can be made between "individual," "group" and "structural" mechanisms.

\section{Individual and Group-level Behavioral Mechanisms}

A great deal of the literature on social mechanisms in general, and policy mechanisms in particular, has focused on the individual level and there is little doubt that individual-level "micro" mechanisms of the type compose one key set of mechanisms.

Until recently most studies focused on so-called "system 1" mechanisms, that is, those that appealed to the more rational bases of human cognition, such as the ability to accurately assess the costs and benefits of specific proposed courses of action and decide upon a maximizing or optimal strategy (Elster, 2009). Under the sway of behavioral economists and others, however, in recent years many works dealing with "system 2" or automatic less "rational" motivations and cognitive strategies have increasingly been added to this lexicon 
Table $3.1 \quad$ A resource-based taxonomy of procedural and substantive policy instruments ${ }^{2}$

\begin{tabular}{|c|c|c|c|c|c|}
\hline & & \multicolumn{4}{|c|}{ Governing Resource and Target Need } \\
\hline & & Information & Authority & Treasure & Organization \\
\hline \multirow[t]{2}{*}{$\begin{array}{l}\text { Purpose } \\
\text { of tool }\end{array}$} & Substantive & $\begin{array}{l}\text { Public } \\
\text { information } \\
\text { campaign }\end{array}$ & $\begin{array}{l}\text { Independent } \\
\text { regulatory agencies }\end{array}$ & $\begin{array}{l}\text { Subsidies } \\
\text { and } \\
\text { grants }\end{array}$ & Public enterprises \\
\hline & Procedural & $\begin{array}{l}\text { Official } \\
\text { Secrets Acts }\end{array}$ & $\begin{array}{l}\text { Administrative } \\
\text { advisory committees }\end{array}$ & $\begin{array}{l}\text { Interest } \\
\text { group } \\
\text { funding }\end{array}$ & $\begin{array}{l}\text { Government } \\
\text { reorganizations }\end{array}$ \\
\hline
\end{tabular}

(Shafir, Simonson and Tversky, 1993; Sunstein et al., 2001; Ariely, 2010; Shafir, 2013). Although often pitched purely at the level of individuals, many of these same mechanisms also operate at the more collective or group level (Olson, 1965; Buchanan, Tolleson and Tulloch, 1980; Riker, 1986).

In this view, at the individual level the mechanisms activated by policy instruments in order to trigger policy change are characteristics of human behavior such as greed, fear, risk aversion, or the use of heuristics and others affect the logics of calculation and appropriateness individuals take towards such issues such as whether or not to perform a crime or quit smoking or invest in a pension fund or donate to a charity (March and Olsen, 2004).

These mechanisms are triggered or activated by "substantive" policy instruments (Howlett, 2000), which are the typical kinds of policy tools discussed in the literature around economic incentives and disincentives such as the provision of subsidies or the creation of regulatory regimes (Tupper and Doern, 1981; Hood, 1986, 1991, 1995; Howlett, 1991; Salamon, 2001). These tools rely on a set of governing resources for their effectiveness, including "nodality" (or information), authority, treasure or the organizational resources of government (Anderson, 1975; Hood, 1986) (Table 3.1).

Thus information-based instruments, for example, can both facilitate the provision of information as well as suppress it, and can involve the release of misleading as well as accurate information (Goodin, 1980). One of the main reasons one tool would be chosen over another was supply oriented: that is, that a government would utilize specific kinds of tools deploying resources it had in ample supply or which could be easily replenished (Hood, 1983).

This is an important insight. But in addition to "supply-side" capacity issues, "demand-side" considerations are also very significant in policy design. That is, in general, each category of tool involves the use of a specific governing resource expected to trigger or lever a specific characteristic or receptor in targets, inducing a certain behavioral response. Thus, the effectiveness of the deployment of such tools is linked not just to resource availability - a precon- 
Table 3.2 Behavioral needs for resource effectiveness

\begin{tabular}{|c|c|c|}
\hline Tool Type & Statecraft Resource Applied & Target Behavioral Prerequisite \\
\hline Nodality & Information & $\begin{array}{l}\text { Credibility/trust: willingness to believe and } \\
\text { act on information provided by government }\end{array}$ \\
\hline Authority & Coercive power/force & $\begin{array}{l}\text { Legitimacy: willingness to be manipulated } \\
\text { by government-invoked penalties and } \\
\text { proscriptions }\end{array}$ \\
\hline Treasure & Financial & $\begin{array}{l}\text { Cupidity: willingness to be manipulated by } \\
\text { gain/losses imposed by governments }\end{array}$ \\
\hline Organization & Organization & $\begin{array}{l}\text { Competence: willingness to receive goods } \\
\text { and services from government and enter into } \\
\text { partnership arrangements }\end{array}$ \\
\hline
\end{tabular}

dition of their use - but also to the existence of different "receptors" on the part of policy targets that make them respond in a predictable way to the use of this resource when deployed.

Table 3.2 presents a model of the behavioral prerequisites that governing tools rely upon for the effect.

In the case of information use, for example, tool effectiveness relies both on the availability of knowledge and the means to distribute it ("resources") and also upon the target's belief in the accuracy of the messages being purveyed, or their credibility ("receptor"). Similarly, the effectiveness of the use of authoritative tools, as discussed above, depends not just on the availability of coercive mechanisms and their enforcement, but also upon target perceptions of government legitimacy. Similarly, the effective use of treasure resources depends not just on the availability of government funding, but also on target group financial need and especially their receptivity to government funding or their cupidity. Likewise, the effective use of organizational tools depends both on the existence of personnel and other organizational resources but also upon target group perceptions of government competence and fairness in the deployment and training of personnel to provide services and rules. This logic is set out in Figure 3.4.

These are important considerations in policy design and especially in the calibration of policy tools. Thus, the use of authority-based tools such as laws and regulations, for example, involves considerations of legitimacy on the part of targets but must not overreach or overburden the extent of legitimacy that a government enjoys (Suchman, 1995; Hanberger, 2003). If a policy measure does so it most assuredly will require much monitoring and enforcement activity to be even minimally effective, involving large administrative costs and burdens that may well undermine its own efficiency and effectiveness 


\section{Design-Output Linkages and Contextual Factors}

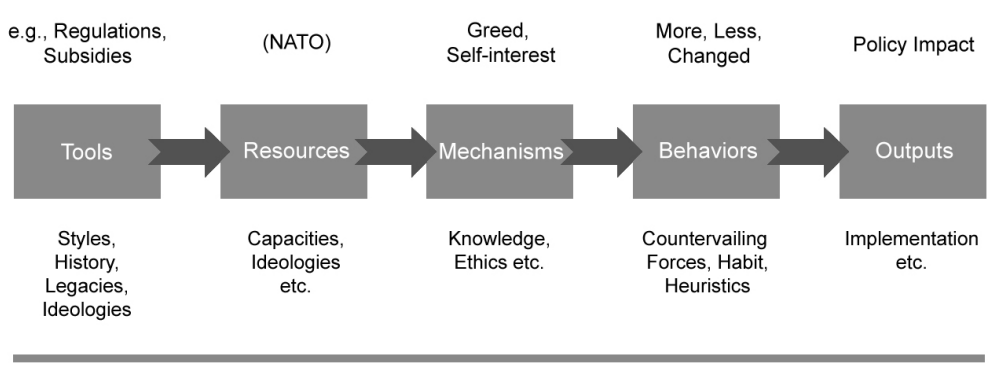

Contextual Barriers and Constraints

Figure 3.4 Links in the design chain - individual and group level

considerations, as has occurred in the past in many countries in areas such as marijuana or alcohol prohibition (Issalys, 2005).

\section{Group-level Mechanisms}

This same logic can be applied to groups or collections of individuals who enter into coalitions in order to pursue collective aims and goals. Such groups are sometimes viewed as mere aggregates of individual preferences with no interests or aims beyond those of their members (Olson, 1965), although more careful study has shown that many more complex motivations and proclivities exist at the collective or organizational level that are not reducible in such a fashion (Halpin and Binderkrantz, 2011). These include propensities to search for new issues or retain existing issue orientations, decisions about whether to specialize or generalize in issue orientations and the nature of membership appeals, for example, rather than simply an interest in membership or revenue growth.

\section{Structural or Subsystem-level Mechanisms}

A third set of mechanisms, however, is the main focus of this chapter: those that affect the structure of policy subsystems. This set of mechanisms is quite different from the individual- or group-level ones that are the typical subjects of mechanistic analysis in that they are less behavioral than structural in nature. 
This important third category of mechanisms is often ignored in the literature on policy mechanisms, which overwhelmingly focuses on the micro or individual level, occasionally venturing into a discussion of the meso or group level.

This third set of mechanisms is activated by many policy tools, especially "procedural" ones that affect the manner in which individuals and groups act and interact in attempting to affect policy outcomes (Howlett, 2000). A sizeable literature in the policy sciences has noted the importance to policy outputs and processes of two aspects of subsystem structure, namely the number of type of actors arrayed in a subsystem or network, and especially their ability to block off or close off entry of new actors, as well as the nature of the ideas that circulate within such subsystems (Howlett and Ramesh, 1998, 2002; Howlett, 2000).

Like any kind of networks, subsystems are composed of nodes and links. Manipulating nodes and links - adding, subtracting and changing them thus constitutes a set of triggers that activate a variety of mechanisms at this network level, including the ability and willingness of policy actors to enter into relationships with other, proximate, actors in the network (rather than more distant ones) or their ability to act as leaders, entrepreneurs or brokers, between other actors and governments. That is, they affect the propensity for subsystems to see the emergence of relatively consistent sets of policy actors and ideas interacting within more or less well-established relational parameters or whether more chaotic relationships and interactions exist.

That is, changes in the ends of policies, be they conceptual or practical, require new ideas to be incorporated into policy-making processes (Hall, 1993; Blyth, 1997; Campbell, 1998; Sabatier, 1999), meaning such ideas have to be able to penetrate into the policy communities and networks that control or dominate policy discourses (Howlett and Ramesh, 1998). Similarly, changes in the conceptual aspects of policy-making can be linked to the ability of actors in policy subsystems to achieve and retain "monopoly" or hegemonic status (Baumgartner and Jones, 1993; Howlett and Rayner, 1995; Jacobsen, 1995; Pontusson, 1995; Hoberg, 1996).

These aspects of subsystem structure are linked to outputs in terms of affecting the propensity for specific types of policy output changes to occur. Policies' goals, for example, tend to change only if there is a simultaneous presence of new actors (as a result of systemic perturbations and/or subsystem spillovers) as well as new ideas (emerging from policy learning and/or change in the venue where policy is made). At the opposite end, minimal changes are accomplished when stability processes such as closed networks and path dependency predominate. Pressures for change from new ideas countered by closed networks tend to lead to changes in policy objectives, while the entrance of new actors into a path-dependent situation is likely to lead only to a change in instruments. At any particular conjuncture, therefore, the propensity for specific types of policy change is determined by the interactive effects of policy 
Table $3.3 \quad$ A model of the structural effects of the presence or absence of new actors and ideas on types of policy change

\begin{tabular}{lll}
\hline & Presence of New Actors & Continuity of Old Actors \\
\hline Presence of New Ideas & Change in goals & Change in objectives \\
Presence of Old Ideas & Change in instruments & Change in settings \\
\hline
\end{tabular}

change and stability processes on subsystem membership and deliberations (Howlett, 2001). The logic of this model is set out in Table 3.3.

Hence, there is a third major type of policy behavior, with a specific set of mechanisms, that policy-makers can, and do, activate, which can be labeled structural ones (Figure 3.5).

\section{Structural Instrument-Output Linkages and Important Contextual Factors}

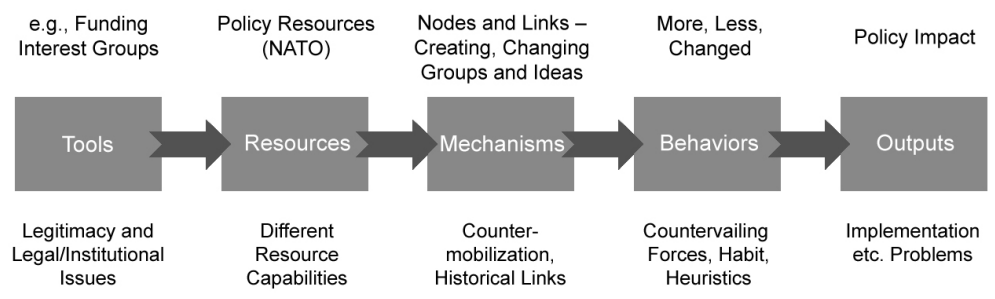

Contextual Barriers and Constraints

Figure 3.5 Links in the design chain-structural level

\section{THE ROLE OF PROCEDURAL TOOLS AS STRUCTURAL MECHANISM ACTIVATORS}

These mechanisms are activated in different ways and with different tools than individual-level behavioral ones. What kinds of policy tools are available for these purposes?

In general, procedural tools are not as well studied as are substantive instruments, and are less well known in their impact and effects, although several techniques such as the use of public participation and administrative reorgani- 
zations are quite old and well used and form the basis of study in fields such as public administration and organizational behavior (Woolley, 2008).

As set out in other chapters, most attention in the literature has been paid to "substantive" tools, that is, those that activate individual and group behavioral mechanisms of the types described above (Hood, 1983, 1986; Howlett, 2000). These tools can affect network structure, such as when, for example, subsidies to an industry lead to the creation of more firms than otherwise would exist, altering the nature of production systems and industrial ecologies. However, procedural policy tools affect aspects of subsystem structure and behavior more directly (De Bruijn and ten Heuvelhof, 1997). They are "the set of techniques by which governmental authorities wield their power in attempting to ensure support and effect social change" (Vedung,1997).

These procedural tools are an important part of network management activities "aimed at improving game (policy) interaction and results" but, as Klijn, Koppenjan and Termeer (1995) also note, the network structures the game without necessarily determining its outcome (p. 441). These tools affect many activities of actors in policy subsystems (Table 3.4).

Procedural tools activate a number of structural mechanisms that affect the number and type of actors and ideas circulating in policy networks (Klijn, Koppenjan and Termeer, 1995; Goldsmith and Eggers, 2004; Klijn and Koppenjan, 2006). They include:

- changing actor policy positions;

- setting down, defining or refining actor positions;

- adding actors to policy networks;

- changing access rules for actors to governments and networks;

- influencing network formation;

- promoting network self-regulation;

- modifying system-level policy parameters (e.g., levels of market reliance);

- changing evaluative criteria for assessing policy outcomes, success and failure;

- influencing the pay-off structure for policy actors;

- influencing professional and other codes of conduct affecting policy actor behavior;

- regulating inter-actor policy conflict;

- changing policy actors' interaction procedures;

- certifying or sanctioning certain types of policy-relevant behavior;

- changing supervisory relations between actors.

Examples of policy tools with this procedural orientation include a government creating an advisory committee of select citizens or experts to aid it in its policy deliberations in contentious issue areas such as local housing development or chemical regulation, or its creation of a freedom-of-information or access-to-information legislation, making it easier for citizens to gain access 
Table $3.4 \quad$ Aspects of policy processes and structures affected by procedural policy tools

\begin{tabular}{|c|c|c|}
\hline & Network Structure & \\
\hline Process & Actors & Interaction \\
\hline Goal formation & $\begin{array}{l}\text { Actors and preferences set-up } \\
\text { Authority } \\
\text { Restrict/invite participation } \\
\text { Information: } \\
\text { Issuing mission statement } \\
\text { Treasure } \\
\text { Funding of participants } \\
\text { Trading influence for compromise and } \\
\text { commitment }\end{array}$ & $\begin{array}{l}\text { Deliberation and consensus orientation } \\
\text { Authority } \\
\text { Rules for decision making (consensus vs } \\
\text { majoritarian) } \\
\text { Interaction guidelines (e.g., joint } \\
\text { declaration of intent) } \\
\text { Information } \\
\text { Providing and acknowledging interest } \\
\text { positions } \\
\text { Treasure } \\
\text { Establishing political opportunity } \\
\text { structures (sponsoring of events/ } \\
\text { secretariat) }\end{array}$ \\
\hline $\begin{array}{l}\text { Effective } \\
\text { implementation }\end{array}$ & $\begin{array}{l}\text { Commitment to deliver results } \\
\text { Authority } \\
\text { Compliance mechanism (binding vs } \\
\text { non-binding) } \\
\text { Accountability } \\
\text { Effective control over implementing } \\
\text { agencies } \\
\text { Information } \\
\text { Reporting } \\
\text { Monitoring } \\
\text { Treasure } \\
\text { Funding of participants }\end{array}$ & $\begin{array}{l}\text { Joint production orientation } \\
\text { Authority } \\
\text { Rules for joint production and } \\
\text { collaboration } \\
\text { Information } \\
\text { Promotion/exhortation of participation } \\
\text { Joint action plans } \\
\text { Treasure } \\
\text { Incentives to collaborate (joint } \\
\text { responsibility) }\end{array}$ \\
\hline
\end{tabular}

to government records, information and documents. Reorganizing their own internal structure can have an effect on policy processes - for example, as occurs when natural resource ministries are combined with environmental ones, forcing the two to adopt some form of new operating arrangements.

\section{CONCLUSION}

A mechanisms approach to policy-making has several advantages over other approaches, not least in how it clarifies the tool-to-output process of policy-making and the key factors and relationships existing in such processes. Many policy mechanisms operate at the level of individual and group behavior and have been discussed elsewhere. However, there is a third class of such 
"first-order" mechanisms that directly affect and change policy subsystem or structure and behavior. This chapter explores this category of network mechanisms, one in which policy tools activate structural components of policy subsystems affecting the number of type of nodes and links present in a policy community or network rather than individual or group behavior per se. Procedural policy tools in particular utilize statecraft resources to activate mechanisms that affect subsystem structural elements - nodes and links - by introducing new actors or reconfiguring relationships in order to affect policy targets and drive policy change. While use of such mechanisms and instruments is common, surprisingly, studies and understanding of them are not. This chapter helps fill this gap in the policy design and mechanisms literature.

\section{NOTES}

1. The use of the term "setting" by Hall has caused some confusion. This term does not refer to the general context or policy environment, but rather to the specific calibration of a policy tool - as in the "settings" for a machine tool or lathe.

2. Cells provide examples of instruments in each category.

\section{REFERENCES}

Aminzade, R. (1992), "Historical sociology and time," Sociological Methods and Research, 20(4), 456-80.

Anderson, J.E. (1975), Public Policymaking, New York: Praeger.

Ariely, D. (2010), Predictably Irrational, Revised and Expanded Edition: The Hidden Forces That Shape Our Decisions, New York: Harper Perennial.

Balch, G. (1980), "The stick, the carrot, and other strategies: A theoretical analysis of governmental intervention," Law \& Policy, 2(1), 35-60.

Baumgartner, F.R. and B.D. Jones (1993), Agendas and Instability in American Politics, Chicago, IL: University of Chicago Press.

Blyth, M.M. (1997), “'Any more bright ideas?' The ideational turn of comparative political economy," Comparative Politics, 29, 229-50.

Buchanan, J.M., R.D. Tolleson and G. Tulloch (1980), Toward a Theory of the Rent-seeking Society, College Station, TX: Texas A\&M Press.

Buckley, W. (1968), "Society as a complex adaptive system," in W. Buckley (ed.), Modern System Research for the Behavioral Scientist, Chicago, IL: Aldine Publishing Company, pp. 490-513.

Bunge, M. (1997), "Mechanism and explanation," Philosophy of the Social Sciences, 27(4), 410-65.

Bunge, M. (2004), "How does it work? The search for explanatory mechanisms," Philosophy of the Social Sciences, 34(2), 182-210. 
Campbell, J.L. (1998), "Institutional analysis and the role of ideas in political economy," Theory and Society, 27(5), 377-409.

Capano, G. (2012), "Policy dynamics and change: The never-ending puzzle," in E. Araral, S. Fritzen and M. Howlett et al. (eds), Routledge Handbook of Public Policy, New York: Routledge, pp. 451-72.

Cater, D. (1964), Power in Washington: A Critical Look at Today's Struggle in the Nation's Capital, New York: Random House.

Daneke, G.A. (1992). "Back to the future: Misplaced elements of political inquiry and the advanced systems agenda," in W.N. Dunn and R.M. Kelly (eds), Advances in Policy Studies Since 1950, New Brunswick, NJ: Transaction Press, pp. 267-90.

Daugbjerg, C. (1997), "Policy networks and agricultural policy reforms: Explaining deregulation in Sweden and re-regulation in the European Community," Governance, 10(2), 123-42.

De Bruijn, J.A. and E.F. ten Heuvelhof (1997), "Instruments for network management," in W.J.M. Kickert, E.-H. Klijn and J.F.M. Koppenjan (eds), Managing Complex Networks: Strategies for the Public Sector, London: Sage, pp. 119-36.

Eisner, M.A. (1994a), "Discovering patterns in regulatory history: Continuity, change and regulatory regimes," Journal of Policy History, 6(2), 157-87.

Eisner, M.A. (1994b), "Economic regulatory policies: Regulation and deregulation in historical context," in D.H. Rosenbloom and R.D. Schwartz (eds), Handbook of Regulation and Administrative Law, New York: Marcel Dekker, pp. 91-116.

Elster, J. (2009), Reason and Rationality, Princeton, NJ: Princeton University Press.

Falleti, T.G. and J.F. Lynch (2009), "Context and causal mechanisms in political analysis," Comparative Political Studies, 42(9), 1143-66.

Glennan, S. (2002), "Rethinking mechanistic explanation," Proceedings of the Philosophy of Science Association, 3, 342-53.

Goldsmith, S. and W.D. Eggers (2004), Governing by Network: The New Shape of the Public Sector, Washington, DC: Brookings Institution.

Goodin, R.E. (1980), Manipulatory Politics, New Haven, CT: Yale University Press.

Hall, P. (1993), "Policy paradigms, social learning and the state: The case of economic policy-making in Britain," Comparative Politics, 25(3), 275-96.

Halpin, D. and A. Binderkrantz (2011), "Explaining breadth of policy engagement: Patterns of interest group mobilization in public policy," Journal of European Public Policy, 18(2), 201-19.

Hanberger, A. (2003), "Public policy and legitimacy: A historical policy analysis of the interplay of public policy and legitimacy," Policy Sciences, 36, 257-8. 
Harris, R. and S. Milkis (1989), The Politics of Regulatory Change, New York: Oxford University Press.

Hedström, P. and R. Swedberg (1996), "Social mechanisms," Acta Sociologica, 39(3), 281-308.

Hedström, P. and R. Swedberg (eds) (1998), Social Mechanisms: An Analytical Approach to Social Theory, New York: Cambridge University Press.

Hedström, P. and P. Ylikoski (2010), "Causal mechanisms in the social sciences," Annual Review of Sociology, 36(1), 49-67.

Hoberg, G. (1996), "Putting ideas in their place: A response to 'Learning and change in the British Columbia Forest policy sector'," Canadian Journal of Political Science, 29(1), 135-44.

Hood, C. (1983), "Using bureaucracy sparingly," Public Administration, 61(2), 197-208.

Hood, C. (1986), The Tools of Government, Chatham, NJ: Chatham House Publishers.

Hood, C. (1991), “A public management for all seasons?” Public Administration, 69, 3-19.

Hood, C. (1995), "Contemporary public management: A new global paradigm?" Public Policy and Administration, 10(2), 104-17.

Howlett, M. (1991), "Policy instruments, policy styles, and policy implementation: National approaches to theories of instrument choice," Policy Studies Journal, 19(2), 1-21.

Howlett, M. (2000), “Managing the 'hollow state': Procedural policy instruments and modern governance," Canadian Public Administration, 43(4), 412-31.

Howlett, M. (2001), "Complex network management and the governance of the environment: Prospects for policy change and policy stability over the long term," in E. Parsons (ed.), Governing the Environment: Persistent Challenges, Uncertain Innovations, Toronto: University of Toronto Press, pp. 303-344.

Howlett, M. (2011), Designing Public Policies: Principles and Instruments, New York: Routledge.

Howlett, M. (2017), "The criteria for effective policy design: Character and context in policy instrument choice," Journal of Asian Public Policy, accessed 8 October 2018 at https://doi.org/10.1080/17516234.2017.1412284.

Howlett, M. (2018), "Matching policy tools \& their targets: Beyond nudges and utility maximization in policy design," Policy \& Politics, 46(1), 101-24.

Howlett, M. and M Ramesh (1998), "Policy subsystem configurations and policy change: Operationalizing the postpositivist analysis of the politics of the policy process," Policy Studies Journal, 26(3), 466-82.

Howlett, M. and M Ramesh (2002), "The policy effects of internationalization: A subsystem adjustment analysis of policy change," Journal of Comparative Policy Analysis, 4(1), 31-50. 
Howlett, M. and M Ramesh (2016), “Achilles' heels of governance: Critical capacity deficits and their role in governance failures," Regulation \& Governance, 10(4), 301-13.

Howlett, M. and J. Rayner (1995), "Do ideas matter? Policy subsystem configurations and the continuing conflict over Canadian forest policy," Canadian Public Administration, 38(3), 382-410.

Howlett, M. and J. Rayner (2013), "Patching vs packaging in policy formulation: Assessing policy portfolio design," Politics and Governance, 1(2), 170-82.

Hupe, P.L. and M.J. Hill (2016), "And the rest is implementation: Comparing approaches to what happens in policy processes beyond great expectations," Public Policy and Administration, 31(2), 103-21.

Issalys, P. (2005), "Choosing among forms of public action: A question of legitimacy," in P. Eliadis, M. Hill and M. Howlett (eds), Designing Government: From Instruments to Governance, Montreal: McGill-Queen's University Press, pp. 154-81.

Jacobsen, J.K. (1995), "Much ado about ideas: The cognitive factor in economic policy," World Politics, 47(2), 283-310.

Kay, A. and P. Baker (2015), "What can causal process tracing offer to policy studies? A review of the literature," Policy Studies Journal, accessed 8 October 2018 at https://doi.org/10.1111/psj.12092.

Klijn, E.H. and J.F. Koppenjan (2006), "Institutional design: Changing institutional features of networks," Public Management Review, 8(1), 141-60.

Klijn, E.H., J. Koppenjan and K. Termeer (1995), "Managing networks in the public sector: A theoretical study of management strategies in policy networks," Public Administration, 73(3), 437-54.

Lang, A. (2016), "Collaborative governance in health and technology policy: The use and effects of procedural policy instruments," Administration \& Society, accessed 8 October 2018 at https://doi.org/10.1177/0095399716664163.

Levitt, B. and J.G. March (1988), "Organizational learning," Annual Review of Sociology, 14, 319-40.

Lindqvist, K. (2016), "Dilemmas and paradoxes of regional cultural policy implementation: Governance modes, discretion, and policy outcome," Administration \& Society, accessed 8 October 2018 at https://doi.org/10 .1177/0095399715621944.

March, J.G. and J.P. Olsen (2004). "The logic of appropriateness," ARENA Working Paper No. 04/09.

McCool, D. (1998), "The subsystem family of concepts: A critique and a proposal," Political Research Quarterly, 51(2), 551-70.

Miller, R.W. (1978), "Methodological individualism and social explanation," Philosophy of Science, 45(3), 387-414.

Olson, M. (1965), The Logic of Collective Action: Public Goods and the Theory of Groups, Cambridge, MA: Harvard University Press. 
Peters, B.G. (1992), "The policy process: An institutionalist perspective," Canadian Public Administration, 35(2), 160-80.

Pontusson, J. (1995), "From comparative public policy to political economy: Putting institutions in their place and taking interests seriously," Comparative Political Studies, 28(1), 117-47.

Riker, W.H. (1986), The Art of Political Manipulation, New Haven, CT: Yale University Press.

Sabatier, P.A. (1988), “An Advocacy Coalition Framework of policy change and the role of policy-oriented learning therein," Policy Sciences, 21, 129-68.

Sabatier, P.A. (1998), "The Advocacy Coalition Framework: Revisions and relevance for Europe," Journal of European Public Policy, 5(1), 98-130.

Sabatier, P.A. (1999), Theories of the Policy Process, Boulder, CO: Westview Press.

Salamon, L.M. (2001), "New governance and the tools of public action: An introduction," The Fordham Urban Law Journal, 28, 1611-74.

Schmidt, V.A. (2008), "Discursive institutionalism: The explanatory power of ideas and discourse," Annual Review of Political Science, 11, 303-26.

Shafir, E. (ed.) (2013), The Behavioral Foundations of Public Policy, Princeton, NJ: Princeton University Press.

Shafir, E., I. Simonson and A. Tversky (1993), "Reason-based choice," Cognition, 49(2), 11-36.

Smith, A. (2000), "Policy networks and advocacy coalitions: Explaining policy change and stability in UK industrial pollution policy?" Environment and Planning C: Government and Policy, 18(1), 95-114.

Suchman, M.C. (1995), "Managing legitimacy: Strategic and institutional approaches," Academy of Management Review, 20(3), 571-610.

Sunstein, C.R., D. Kahneman, D. Schkade and I. Ritov (2001), "Predictably incoherent judgments," U. Chicago Law \& Economics, Olin Working Paper No. 131, accessed 8 October 2018 at https://papers.ssrn.com/sol3/papers .cfm?abstract id=279181.

Tupper, A. and G.B. Doern (1981), "Public corporations and public policy in Canada," in A. Tupper and G.B. Doern (eds), Public Corporations and Public Policy in Canada, Montreal: Institute for Research on Public Policy, pp. 1-50.

Vedung, E. (1997), "Policy instruments: Typologies and theories," in E. Vedung, M.L. Bemelmans-Videc and R.C. Rist (eds), Carrots, Sticks and Sermons: Policy Instruments and Their Evaluation, New Brunswick, NJ: Transaction Publishers, pp. 21-58.

Weaver, R.K. (2014), "Compliance regimes and barriers to behavioral change," Governance, 27(2), 243-65.

Weaver, R.K. (2015), “Getting people to behave: Research lessons for policy makers," Public Administration Review, accessed 8 October 2018 at https:// onlinelibrary.wiley.com/doi/abs/10.1111/puar.12412. 
Wilsford, D. (1994), "Path dependency, or why history makes it difficult but not impossible to reform health care systems in a big way," Journal of Public Policy, 14(3), 251-84.

Woolley, A. (2008), "Legitimating public policy," University of Toronto Law Journal, 58(2), 153-84.

Wu, X., M Ramesh and M. Howlett (2015), "Policy capacity: A conceptual framework for understanding policy competences and capabilities," Policy and Society, Special Issue on the Dynamics of Policy Capacity, 34(3-4), 165-71. 